\title{
Physiological quality of pelleted Cubiu (Solanum sessiliflorum Dunal) seeds
}

\author{
Layanne Muniz Sprey ${ }^{1}$, Sidney Alberto do Nascimento Ferreira ${ }^{1}$, Maylla Muniz Sprey ${ }^{1}$
}

Abstract- The objective of this study was to evaluate the effect of different coating materials on the physiological quality of cubiu seeds. This was evaluated with three agglomerate materials (manioc starch, inert talc and dolomitic limestone) and two binder polymers (polyvinyl acetate and gum arabic) with 30\% concentration, and artificial dye finishing. The experimental design was completely randomized, in factorial scheme 3 (agglomerates) x 2 (binders), and additional treatment (bare seeds/control), containing four replicates and experimental units of fifty seeds/ pellets. The seeds were evaluated for: yield; seed/pellet diameter; thousand seed weight; number of seeds per pellets; germination; germination speed index; mean germination time, seedling length; fresh and dry mass of the seedling and emergence. In general, pelletizing increased the weight and diameter of the propagation unit. The physical barrier applied to the seeds by pelletizing did not influence the germination, but delayed the germination rate concerning to bare seeds, and this effect was not observed in emergence seedling. The coating with dolomitic limestone and polyvinyl acetate presented the best results of germination and vigor.

Index terms: Solanaceae, seed coating, germination, vigor.

\section{Qualidade fisiológica de sementes peletizadas de Cubiu (Solanum sessiliflorum Dunal)}

Corresponding author: layannesprey14@gmail.com

Received: June 26, 2018 Accepted: January 04, 2019

Copyright: All the contents of this journal, except where otherwise noted, is licensed under a Creative Commons Attribution License.

\section{(cc) $\mathbf{E}$ Y}

Resumo - Objetivou-se com este trabalho avaliar o efeito de distintos materiais de recobrimento na qualidade fisiológica de sementes de cubiu. Para tanto, foram testados três materiais aglomerantes (fécula de mandioca, talco inerte e calcário dolomítico) e dois polímeros aglutinantes (acetato de polivinila e goma arábica) na concentração de $30 \%$, e, ao final, acabamento com corante artificial. $\mathrm{O}$ delineamento experimental foi o inteiramente casualizado, em esquema fatorial 3 (aglomerantes) x 2 (aglutinantes), mais tratamento adicional (sementes nuas/testemunha), com quatro repetições e cinquenta sementes/péletes por unidade experimental. As sementes foram avaliadas quanto ao: rendimento; diâmetro das sementes/péletes; massa de mil sementes; número de sementes por péletes; germinação; índice de velocidade de germinação; tempo médio de germinação, comprimento da plântula; massa fresca e seca da plântula e emergência. De maneira geral, a peletização aumentou a massa e o diâmetro da unidade de propagação. A barreira física imposta às sementes pela peletização não influenciou na germinação, mas promoveu atraso na velocidade de germinação em relação às sementes nuas, não sendo observado esse efeito na emergência. $O$ recobrimento com calcário dolomítico e acetato de polivinila apresentou os melhores resultados de germinação e vigor.

Termos para indexação: Solanaceae, recobrimento de semente, germinação, vigor. 


\section{Introduction}

The cubiu (Solanum sessiliflorum Dunal), belongs to the Solanaceae family, also known as maná, manácubiu, topiro and indigenous tomato, originated from the Western Amazon, with distribution throughout the Brazilian, Peruvian and Colombian Amazon (ANDRADE JÚNIOR et al., 2017). Its fruits are used on in natura form or industrially processed for food, pharmaceutical and cosmetic purposes (DONADIO; ZACCARO, 2012). It presents economic potential, given its rusticity, high fruit yield, nutritional value and multiplicity uses (SILVA FILHO et al., 2012a).

The plant is herbaceous, predominantly autogamous and of annual cycle. It has a wide phenotypic variability, with berry type fruits, coloration between green to reddish brown of various sizes and formats, from subglobous to ovoid. Internally, it is formed by four to eight locules, containing from 500 to 2,000 small and flattened seeds, protected by placental mucilage, in which one gram of seeds can collect 1,000 units (SILVA FILHO et al., 2013).

Seeds of reduced size and mass are difficult to individualize at sowing. These aspects can cause irregularity in seed spacing and density, leading to seeds waste and need for thinning of surplus plants or "replanting", in case of failure, to obtain a satisfactory stand of plants in the crop. These operations require a greater use of labor, raising the cost of production (SAMPAIO; SAMPAIO, 2009).

Among the methods and technologies proposed to repair the problem of these species is the use of seed coating. In the last decades, this technique has been widely used in forest seeds, vegetables, leguminous and forage grasses (SIKHAO et al., 2015). It can also serve as a carrier for the incorporation of nutrients, inoculants, growth regulators and other agrochemicals (QUEIROZ et al., 2015).

Pelletizing is one of the coating techniques that provides the modification of the seeds physical characteristics, through the application of different dry materials and binder polymers, which, adhered to the seed surface, increase size and mass, besides the spherical shape (SANTOS, 2016). At the end of the process, the pellets should have physical properties of not being disrupted during transportation, handling and sowing. However, when moistened after sowing, they should disintegrate easily, so that pelleting does not constitute a physical barrier that prevents germination (HÖLBIG et al., 2010).

The pellet layer on the seed is relatively thin, formed of well-arranged and interconnected particles, taking into account the interaction between inert and binders products, and their influence on the pellet stiffness. The preparation of the pellets is accomplished by intermittent application of filler materials with the application of adhesive agent on the seeds. Such process is carried out in equipment involving stirring and/or vibration systems, consisting mainly of mixers, centrifuges and barrels (LOPES; NASCIMENTO, 2012).

Seed pelletizing provides numerous benefits, such as improved manual and mechanical planting; protection against mechanical damage; reduction of thinning practice; improved efficiency of plant protection products adhered to pellets; improved visualization of the seeds in the soil or substrate. However, the barrier imposed by the material under the seeds may result in antagonistic effects, such as: making it difficult to emit the primary root; to intervene in the gas exchanges between the seed and the external environment to the pellet and promote the unequivocal emergence of the seedlings (SILVA; NASCIMENTO, 2009).

In this way, it is necessary to establish interaction between the materials, with the most suitable granulometry and the best proportion of the ingredients. Thus, the objective of this study was to evaluate the combination of different coating materials on the physiological quality of pelleted seeds of cubiu (Solanum sessiliflorum).

\section{Material and Methods}

The study was carried out at the Seeds Laboratory and in the Germination Nursery of the Biodiversity Coordination (COBIO) of the National Institute of Amazonian Research (INPA), Campus III (V8), in Manaus, Amazonas. The fruits of cubiu used were of the cultivar "Moacir", of the collection of germplasm of the INPA (SILVA FILHO et al., 2013), cultivated in the Experimental Farm of the Federal University of Amazonas ( $2^{\circ} 39^{\prime} 50^{\prime \prime}$ S and $60^{\circ} 03^{\prime} 07^{\prime}$ 'W, 94 meters altitude), State of Amazonas, Brazil.

The fruits harvested presented the epicarp of dark red color, with mean mass of $265.72 \mathrm{~g}$, mean length of $9.40 \mathrm{~cm}$ and mean diameter of $7.49 \mathrm{~cm}$.

Seeds were manually benefited with asepsis in $0.5 \%$ sodium hypochlorite solution for five minutes under stirring. After, the seeds were washed in running water and placed on paper towels to remove water excess. Afterwards, 3 replicates of $1 \mathrm{~g}$ were taken to determine the degree of humidity in an oven at $105 \pm 3{ }^{\circ} \mathrm{C}$ for 24 hours (BRASIL, 2009). The seeds were submitted to drying in an oven at $30{ }^{\circ} \mathrm{C}$ for 12 hours, reaching a moisture content of $8 \%$.

The seed pelletizing process was performed in automated equipment involving a stirring system, with rounded bulge with a capacity of 4 liters, inclination of $45^{\circ}$ and adjustable rotation speed at $35 \mathrm{rpm}$. A manual compression sprayer with a capacity of 1.5 liters was used in the application of the cements (binders). To add the filler materials (agglomerates) into the apparatus, a fine mesh $(0.5 \mathrm{~mm}), 15 \mathrm{~cm}$ diameter sieve was used. The 
pelletizing procedure lasted on average 35 minutes per start, without considering the drying period and the time to prepare material.

The coating process was carried out with $10 \mathrm{~g}$ of seeds for each treatment. The seeds were inserted into the moving equipment, and underwent numerous rotations, at the same time as they received the cement solutions in 3 second jets. After uniform distribution of each cement solution, the filler was added, divided into small fractions of 3 to $5 \mathrm{~g}$, with a final value of $100 \mathrm{~g}$. These values were adopted for all fillers because they were shown to be suitable for forming a layer on all seeds. The application of the cement solution and the filler was alternated until there was no more visible integument forming spherical granules of smooth surface and, at the end of the procedure, the application of the finishing material (dye) was done.

For the preparation of the pellets (Figure 1), three fillers were used: manioc starch, inert talc and dolomite limestone, gradually sieved and applied alternately with the pulverization of cement solutions. As a cementing material, gum arabic and polyvinyl acetate (PVA), diluted in water heated at $70{ }^{\circ} \mathrm{C}$ (MENDONÇA et al., 2007), at a concentration of $30 \%$ (SILVA; NAKAGAWA, 1998) were used, and, at the end, finishing with artificial food coloring. Subsequently, the pellets were homogenized in round sieve screens and the seeds with a diameter of 3 to 5 $\mathrm{mm}$ were used in the tests. They were then dried in an oven at $38^{\circ} \mathrm{C}$ for 24 hours (LOPES; NASCIMENTO, 2012).

The physical characteristics and the physiological quality of the seeds were evaluated by means of the following variables:

Yield per pellet size: after they were made, the pellets were classified by size into three categories: $<3$ $\mathrm{mm}$ - pellets that passed through the sieve with circular sieves of size $3 \mathrm{~mm} ; 3 \geq \mathrm{x} \leq 5 \mathrm{~mm}$ - pellets that passed through the $5 \mathrm{~mm}$ circular sieve and were retained in the sieve with $3 \mathrm{~mm}$ circular sieves; $>5 \mathrm{~mm}$ - pellets that did not pass through the sieve with $5 \mathrm{~mm}$ circular sieves. The results were expressed as percentage, based on the gram mass of each category.

Diameter of seeds/pellets: for the determination of the transverse diameter, 50 bare and pelleted seeds of each treatment were chosen at random and individually measured with a $0.01 \mathrm{~mm}$ precision digital caliper.

Mass of one thousand seeds/pellets: determined according to Brazil (2009) with eight replicates of 100 seeds/pellets, and the result expressed in mean mass of one thousand seeds (grams).

Number of seeds per pellets: using five samples of 10 pellets from each treatment, the "unpelletizing" was done crushing the sample to separate the seed and quantifying the number of units present in each pellet.

Germination: Four replicates of 50 seeds/pellets were placed in a transparent plastic box $(11 \times 11 \times 3.5$ $\mathrm{cm}$ ) on blotting paper, moistened with distilled water, in the ratio of 3 times the mass of the dry paper. The seeds/ pellets were kept in a germination chamber, at a constant temperature of $30^{\circ} \mathrm{C}$, with photoperiod of 12 hours. Seeds/ pellets that showed protrusion of the primary root with final count at the $30^{\text {th }}$ day after the test installation were considered germinated (BRASIL, 2009).

Normal seedlings: performed at the end of the germination test, counting the number of seedlings that had all well developed, complete and healthy structures (BRASIL, 2009).

Germination speed index: applied in conjunction with the germination test, which computed the number of germinated seeds per day, divided by the number of days elapsed between sowing and germination, and whose index was calculated according to the formula proposed by Maguire (1962).

Mean germination time: obtained by daily counting of germinated seeds up to the thirtieth day after sowing and calculated using the formula proposed by Labouriau (1983).

Emergence: four replicates of 50 seeds/pellets sown in plastic trays $(26 \times 17 \times 6 \mathrm{~cm})$ containing commercial substrate were used. They were then kept in a greenhouse, with a minimum average temperature of $26^{\circ} \mathrm{C}$ and maximum of $38{ }^{\circ} \mathrm{C}$. Seeds/pellets presenting the cotyledonary leaves above the surface of the substrate were considered as emerged, with a final count at 50 days after the test installation (BRASIL, 2009). The emergence speed index (ESI) was calculated according to the formula proposed by Maguire (1962) and the mean emergence time (MET) calculated using the formula proposed by Labouriau (1983).

Seedling length: At the end of the germination test, the height of normal seedlings of each replicate were measured taking the length of the main root until the insertion of the first leaf, with graduated ruler in centimeters, the results being expressed in $\mathrm{cm}$ seedlings ${ }^{-1}$.

Fresh and dry mass of the seedling: the normal seedlings of each replicate were weighed and packed in paper bags and taken to dry in oven with forced air circulation at $80^{\circ} \mathrm{C}$ for 24 hours (NAKAGAWA, 1999). After this period, the samples were placed to cool in desiccators and then weighed in a precision scale, the results being expressed in grams of seedling ${ }^{-1}$.

Experimental design: the experiment was conducted in a completely randomized design, in a factorial scheme of 3 (fillers materials) x 2 (cementing materials), plus additional treatment (bare seeds/control). The results were submitted to the analysis of variance and the control mean regarding to the treatments was compared by the Dunnett test, while for the means of the factor levels individually, as well as the interaction between them, the Tukey test was applied, all at 5\% probability level, using the ASSISTAT program version 7.7 (SILVA; AZEVEDO, 2016). 


\section{Results and Discussion}

The coating processes of cubiu seeds provided different sizes of pellets, with a predominance of sizes from 3 to $5 \mathrm{~mm}$, which, regardless of the procedure adopted, represented on average $67 \%$ (Table 1). In this category, the pellets prepared with gum arabic and inert talc presented a higher proportion (77.32\%), whereas gum arabic and manioc starch lower proportion (58.74\%), and the other processes intermediate values. Pellets larger than $5 \mathrm{~mm}$ were in the lowest proportion (3\%), and the use of gum arabic, irrespective of the filling material, gave the highest percentages. With respect to pellets less than 3 $\mathrm{mm}$, these had a considerable participation, representing on average $30 \%$; gum arabic and manioc starch presented higher value (36.16\%) and gum arabic and inert talc the lowest (19.37\%). According to Sousa et al. (2016), the formation of different sizes of pellets is due to the different types and texture of the materials used and also to the disposal of them in the coating process.

The seed coating promoted an increase in the propagation units' mass of the order of 19 to 39 times compared to the bare seeds (Table 1). The use of dolomitic limestone, regardless of the cementing material, provided the largest increase (38 to 39 times), while the other fillers (manioc starch and inert talc), associated with different cements, had smaller increases (19 to 22 times). Certainly, this was due to the higher density of the dolomitic limestone $\left(2.87 \mathrm{~g} \mathrm{~cm}^{-3}\right)$ concerning to manioc starch $(1.56$ $\left.\mathrm{g} \mathrm{cm}^{-3}\right)$ and the inert talc $\left(0.58 \mathrm{~g} \mathrm{~cm}^{-3}\right)$. Although they have different densities, the similarity of the mass gains between the pellets with manioc starch and with inert talc can be associated to the loss of material in the equipment and in the drying process. The benefit of increasing the mass and the size of the propagation unit lies in the easiness of sowing, whether manual or mechanized (GADOTTI; PUCHALA, 2010).

The diameters of the pellets showed that the coating provided an increase in size from 8 to 10 times compared to the bare seeds (Figure 2), with modification of the propagation units, becoming spherical. The use of dolomitic limestone contributed to the formation of pellets with a larger diameter $(3.83 \pm 0.06 \mathrm{~mm})$, followed by inert talc $(3.65 \mathrm{~mm})$ and manioc starch $(3.36 \pm 0.03$ $\mathrm{mm})$, regardless of the adhesive material employed.

The smaller diameter of the seeds pelletized with manioc starch was probably due to saturation of the coating by the coating material and consequently the surplus material adhered to the bulge of the equipment and/or loss in the drying process. Luwing et al. (2011) state that the loss of material in the seed coating process can be minimized by tailoring the methodology for each specific product and/or regulating the equipment at each material change.

The number of seeds per pellet (NSP) differed from the control (bare seeds) (Table 2). Regarding the filling and cementing factors, in addition to the interaction between them, the NSP did not present a significant effect, with a general average of 1.21 seeds per pellet, presenting from 1 to 3 units per granules: $82 \%$ of the pellets contained one seed; $14 \%$ contained two; and $4 \%$ three seeds. This result is according to Silva; Nascimento (2009), who consider that the pelletized seeds can carry one or more seeds, most of them being only one seed per pellet.

As for germination, it was observed that the treatments of pelleting did not influence the germination process compared to bare seeds (Table 2), as well as no significant effect was observed for the interaction between the studied factors (filler and cementing). On the other hand, singly, both the filling material and the cementing material presented significant differences between their levels. The use of dolomitic limestone promoted superior value (89\%) concerning to inert talc $(65 \%)$ and manioc starch (63\%). Regarding the cements, the use of polyvinyl acetate was superior $(80 \%)$ to gum arabic $(63 \%)$. Evaluating the rice (Oryza sativa) seed coating, Tavares et al. (2012) observed that the use of dolomitic limestone provided germination above $85 \%$. Nascimento et al. (2009) reported that the use of gum arabic in pelleted carrot (Daucus carota) seeds promoted the lowest germination values.

For the normal seedling variable, the applied treatments did not differ significantly from the control (bare seeds) and the factors filling and cementing had an interaction effect (Table 3). The use of polyvinyl acetate was not influenced by the type of filler, whereas with the use of gum arabic, the use of dolomitic limestone provided superior results. The inert talc and dolomitic limestone did not differ as to the cementing material used, whereas, when using manioc starch, pellets made of polyvinyl acetate showed superior results. The lowest percentage of normal seedlings obtained in the association of manioc starch and gum arabic was due to the presence of fungi Aspergillus sp., which compromised their development. This was also observed by Mendonça et al. (2007) in the germination of corn-coated (Zea mays) seeds, which attributed the use of organic products, based on starch and sugar in the coating, which are easily digested and proliferation of pathogenic microorganisms.

Concerning to the germination speed index (GSI) and the mean germination time (MGT), it was observed that bare seeds germinated faster than pelleted seeds, although for MGT the difference was not significant (Table 2). In the material filling factor, the GSI for dolomitic limestone $\left(3.93 \%\right.$ day $\left.^{-1}\right)$ was higher than manioc starch $\left(2.21 \%\right.$ day $\left.^{-1}\right)$ and both did not differ significantly from inert talc $\left(2.90 \%\right.$ day $\left.^{-1}\right)$. As for the cementing material factor, polyvinyl acetate excelled compared to gum arabic with similar behavior for the variables GSI and MGT.

Carvalho and Novembre (2011), studying coated 
tobacco (Nicotiana tabacum) seeds, observed that the germination is slower than in the uncoated ones. Pereira et al. (2011) also report that the coated seeds take longer to absorb moisture and may delay germination, but despite this delay, final germination rates are similar to those of bare seeds. Caldeira et al. (2016) mention that the material used in the pelletizing process can act as a physical barrier for the emission of the primary root, causing delay in the speed of germination.

The length of the seedlings did not present significant difference between the control and the treatments, and there was not interaction effect between the tested factors. On the other hand, isolated filler and cementing material presented differences between their levels (Table 2). As a filling material, dolomitic limestone $(6.11 \mathrm{~cm})$ achieved a better result than that obtained by inert talc $(4.75 \mathrm{~cm})$ and manioc starch $(2.81 \mathrm{~cm})$. With respect to the cementing material, polyvinyl acetate $(5.30$ $\mathrm{cm})$ presented a better result than that obtained with gum arabic $(3.81 \mathrm{~cm})$. Sampaio and Sampaio (2009) report that the external nutritional contribution, through the coating of seeds with early fertilizer supply, makes the seedlings respond favorably to growth in a faster and more vigorous way.

In the seedling fresh and dry mass, significant differences were observed between the treatments and the control (Table 2). These variables had similar behavior regarding the filling material, where the use of dolomitic limestone gave significantly higher results than those obtained with inert talc and manioc starch. According to Tavares et al. (2012), rice seedlings coated with dolomitic limestone had seedlings with a higher fresh mass than the other materials (aluminum silicate and aluminum silicate plus dolomitic limestone). Regarding the cementing material, the fresh mass showed no significant difference between gum arabic and polyvinyl acetate. However, for the dry mass the polyvinyl acetate presented better results than the gum arabic.

When the seed performance on the substrate was evaluated, the emergence of the pelleted seeds did not differ significantly from the control (Table 4) and there was no interaction effect between the factors studied. Within the filling factor material, manioc starch $(97 \%)$ and dolomitic limestone (86\%) did not differ among them, and inert talc (79\%) presented lower value. Santos et al. (2011) found that seedling emergence of Brachiaria brizantha was not reduced by the recoating process, and that the value reached was higher than that of the laboratory (germination).

Regardless of the treatments stand out the highest emergence values when compared to the germination, which is not normally expected. Although the germination test was conducted in a period of 30 days and the emergence test up to 50 days. According to Silva Filho et al. (2012b), the germination of cubiu seeds occurs from the $7^{\text {th }}$ day and extends up 40 days. In addition, a constant temperature $\left(30^{\circ} \mathrm{C}\right)$ was used in the germination test, while in the emergence test the temperature ranged from a mean minimum value of $26^{\circ} \mathrm{C}$ to an average maximum of $38^{\circ} \mathrm{C}$. According to Lopes and Pereira (2005), the seeds of cubiu present better germination when submitted to the temperature alternating between 20 to $30^{\circ} \mathrm{C}$, and the constant temperature of $30{ }^{\circ} \mathrm{C}$ retards the germination process of the seeds.

Regarding the emergence speed index (ESI), there was no significant difference between the control and the treatments, as well as between the filling and cementing factors (Table 4). According to Bomfim et al. (2016), the bare quinoa (Chenopodium quinoa) seeds present a higher germination speed than the pelleted seeds when tested in the laboratory, but there is no difference between these treatments in a greenhouse.

The mean emergence time (MET), fresh mass (FM) and dry mass (DM) had a similar behavior, except for MET that showed a significant difference between bare seeds and the treatments (Table 4). Concerning to the filling material, dolomitic limestone and inert talc stood out in relation to manioc starch. However, within the cementing material factor, all these variables did not present significant difference between gum arabic and polyvinyl acetate. According to Dode et al. (2012), seedlings presenting fresh and dry mass superior to the others, for the same species, indicate good physiological quality of the seeds, and are considered more vigorous. 


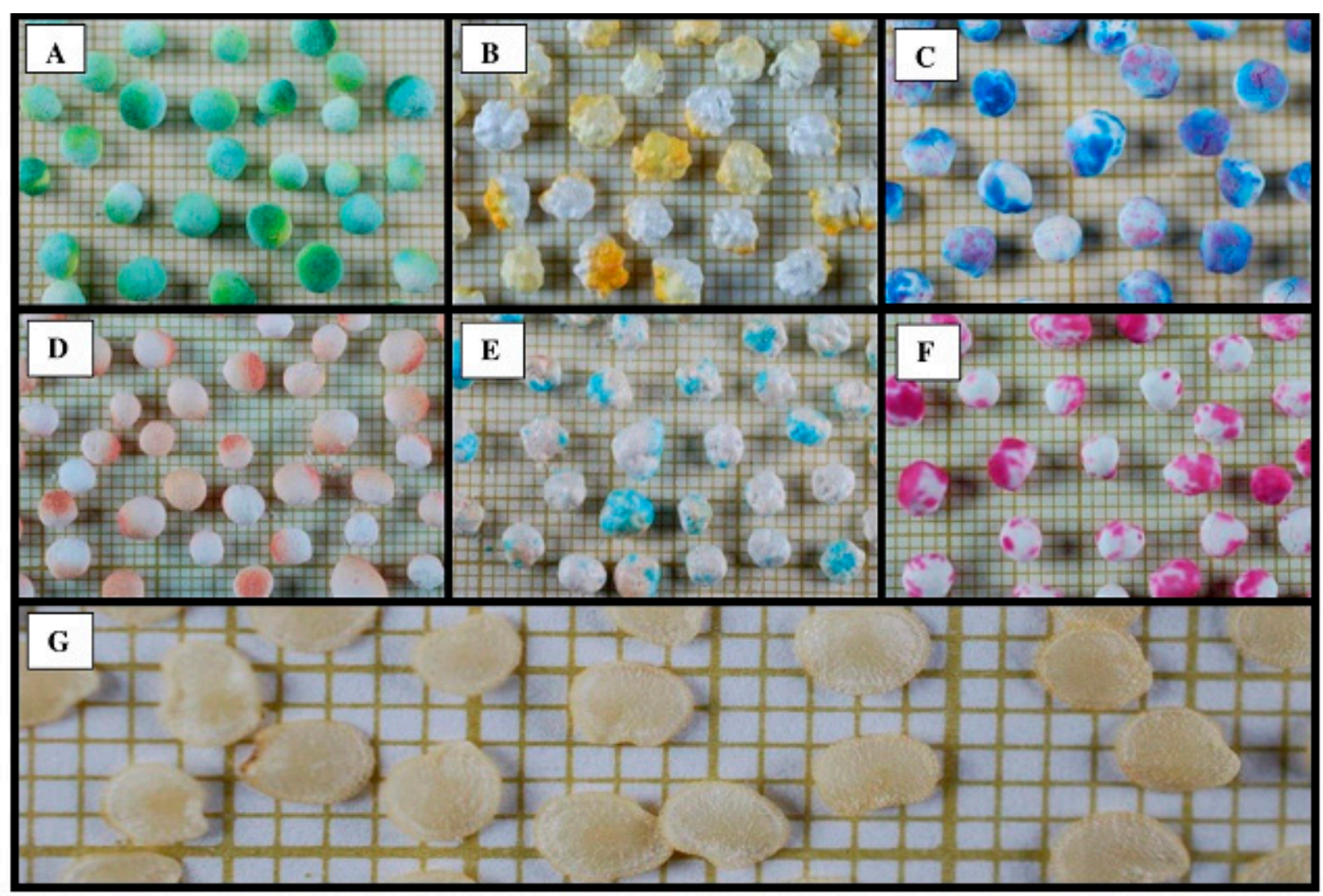

Figure 1. Pelleted cubiu seeds (scale in $\mathrm{mm}$ ): $\mathrm{A}=$ gum arabic + dolomitic limestone; $\mathrm{B}=$ gum arabic + inert talc; $\mathrm{C}$ $=$ gum arabic + manioc starch $; \mathrm{D}=$ polyvinyl acetate + dolomitic limestone; $\mathrm{E}=$ polyvinyl acetate + inert talc; $\mathrm{F}=$ polyvinyl acetate + manioc starch; $\mathrm{G}=$ bare seeds.

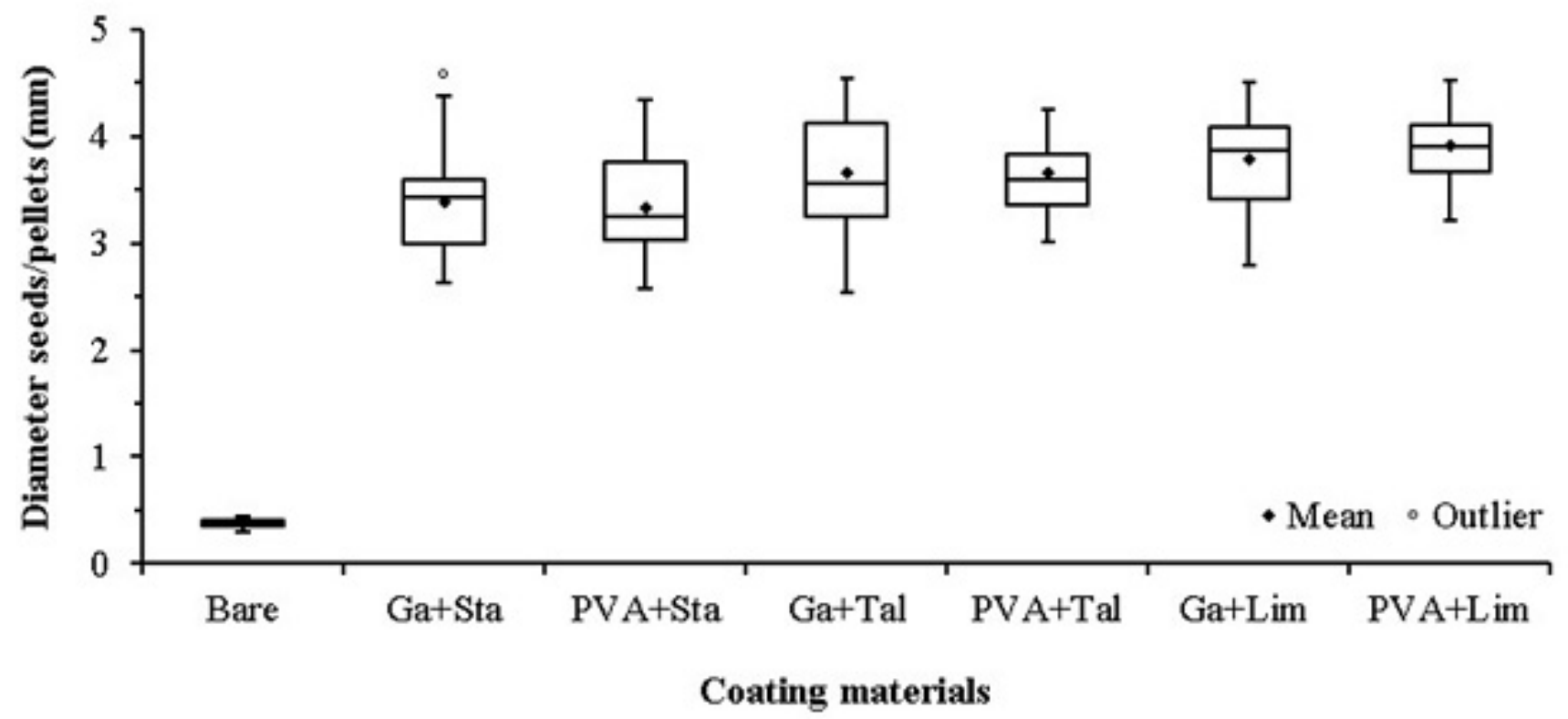

Figure 2 - Box plot of dispersion of the diameter values of bare (control) and pelleted cubiu seeds. Cementing: Ga= Gum arabic; PVA = Polyvinyl acetate; Filling: Sta = Manioc starch; Tal: Inert talc; Lim = Dolomitic limestone. 
Table 1. Classification of cubiu seed pellets in percentage (\%), based on the mass of each size category, and the mass of one thousand seeds/pellets.

\begin{tabular}{lcccc}
\hline Treatments & \multicolumn{3}{c}{ Size categories (mm) } & Mass of one thousand \\
\cline { 2 - 4 } & $<3$ & $\geq 3 \mathrm{e} \leq 5$ & $>5$ & seeds/pellets (g) \\
\hline Bare seeds & - & - & - & 1.00 \\
Gum arabic + manioc starch & 36.16 & 58.74 & 5.10 & 20.46 \\
Polyvinyl acetate + manioc starch & 34.36 & 63.91 & 1.73 & 21.69 \\
Gum arabic + inert talc & 19.37 & 77.32 & 3.30 & 21.09 \\
Polyvinyl acetate + inert talc & 29.09 & 69.20 & 1.71 & 19.28 \\
Gum arabic + dolomitic limestone & 26.84 & 70.20 & 2.95 & 39.39 \\
Polyvinyl acetate + dolomitic limestone & 34.22 & 64.67 & 1.11 & 37.78 \\
\hline Average (\%) & 30.0 & 67.3 & 2.7 & - \\
\hline
\end{tabular}

Table 2. Number of seeds per pellet (NSP), germination (G), germination speed index (GSI), mean germination time (MGT), seedling length (SL), fresh mass (FM) and dry mass (DM) of the seedling, referring to bare seeds (control) and pelletized cubiu seeds.

\begin{tabular}{|c|c|c|c|c|c|c|c|}
\hline Factor & NSP & $\begin{array}{c}\mathbf{G} \\
(\%)\end{array}$ & $\begin{array}{c}\text { GSI } \\
\left(\% \text { day }^{-1}\right)\end{array}$ & $\begin{array}{l}\text { MGT } \\
\text { (days) }\end{array}$ & $\begin{array}{c}\text { SL } \\
(\mathrm{cm})\end{array}$ & $\begin{array}{l}\text { FM } \\
(\mathrm{g})\end{array}$ & $\begin{array}{l}\text { DM } \\
\text { (g) }\end{array}$ \\
\hline Control & $1 *$ & $68^{\text {ns }}$ & $4.02 *$ & $10.86^{\text {ns }}$ & $4.90^{\mathrm{ns}}$ & $0.30 * *$ & $0.02 * *$ \\
\hline \multicolumn{8}{|c|}{ Filling material } \\
\hline Starch & $1.36 \mathrm{a}$ & $63 \mathrm{~b}$ & $2.21 \mathrm{~b}$ & $15.93 \mathrm{a}$ & $2.81 \mathrm{c}$ & $0.47 \mathrm{~b}$ & $0.07 \mathrm{~b}$ \\
\hline Talc & $1.18 \mathrm{a}$ & $65 \mathrm{~b}$ & $2.90 \mathrm{ab}$ & $14.30 \mathrm{a}$ & $4.75 \mathrm{~b}$ & $0.49 \mathrm{~b}$ & $0.10 \mathrm{~b}$ \\
\hline Limestone & $1.18 \mathrm{a}$ & $89 \mathrm{a}$ & $3.93 \mathrm{a}$ & $13.00 \mathrm{a}$ & $6.11 \mathrm{a}$ & $0.89 \mathrm{a}$ & $0.22 \mathrm{a}$ \\
\hline \multicolumn{8}{|c|}{ Cementing material } \\
\hline $\mathrm{Ga}$ & $1.21 \mathrm{a}$ & $63 \mathrm{~b}$ & $2.20 \mathrm{~b}$ & $16.67 \mathrm{~b}$ & $3.81 \mathrm{~b}$ & $0.60 \mathrm{a}$ & $0.11 \mathrm{~b}$ \\
\hline PVA & $1.26 \mathrm{a}$ & $80 \mathrm{a}$ & $3.82 \mathrm{a}$ & $12.15 \mathrm{a}$ & $5.30 \mathrm{a}$ & $0.64 \mathrm{a}$ & $0.15 \mathrm{a}$ \\
\hline $\mathrm{CV}(\%)$ & 16.11 & 16.57 & 26.85 & 26.95 & 14.05 & 24.94 & 27.83 \\
\hline
\end{tabular}

Filling material: Starch $=$ manioc starch; Talc: inert talc; Limestone $=$ dolomitic limestone.

Cementing material: $\mathrm{Ga}=$ Gum arabic; $\mathrm{PVA}=$ Polyvinyl acetate.

ns - comparison between control and treatments, not significant by the F test at the $5 \%$ level.

* - comparison between control and treatment, significant by the $\mathrm{F}$ test at the $5 \%$ level.

** - comparison between control and treatment, significant by the $\mathrm{F}$ test at the $1 \%$ level.

Means followed by the same letter, in the column and within each factor, do not differ among themselves by the Tukey test, at a $5 \%$ probability level.

Table 3. Normal seedling regarding to the interaction of the filler and cementing material used in the pelletizing of cubiu seeds.

\begin{tabular}{lccc}
\hline \multirow{2}{*}{ Cementing material } & \multicolumn{3}{c}{ Filling material } \\
\cline { 2 - 4 } & Manioc starch & Inert talc & Lime. dolomite \\
\hline Gum arabic & $35 \mathrm{bB}$ & $56 \mathrm{aB}$ & $87 \mathrm{aA}$ \\
Polyvinyl acetate & $78 \mathrm{aA}$ & $71 \mathrm{aA}$ & $87 \mathrm{aA}$ \\
\hline $\mathrm{CV}(\%)$ & & 20.99 & \\
\hline
\end{tabular}

Means followed by the same lowercase letter in the column and the same uppercase letter in the row do not differ from each other by the Tukey test, at a $5 \%$ probability level.

Table 4. Emergency (E), emergency speed index (ESI), mean emergence time (MET), fresh mass (FM) and dry mass (DM) of the seedling, regarding to bare (control) and pelleted cubiu seeds.

\begin{tabular}{|c|c|c|c|c|c|}
\hline Factor & $\begin{array}{c}E \\
(\%)\end{array}$ & $\begin{array}{c}\text { ESI } \\
\left(\% \text { day }^{-1}\right)\end{array}$ & $\begin{array}{c}\text { MET } \\
\text { (days) }\end{array}$ & $\begin{array}{c}\text { FM } \\
(\mathrm{g}) \\
\end{array}$ & $\begin{array}{c}\text { DM } \\
(\mathrm{g})\end{array}$ \\
\hline Control & $78^{\mathrm{ns}}$ & $1.45^{\mathrm{ns}}$ & $18.06^{* *}$ & $14.91^{\mathrm{ns}}$ & $1.26^{\mathrm{ns}}$ \\
\hline \multicolumn{6}{|c|}{ Filling material } \\
\hline Starch & $97 \mathrm{a}$ & $1.24 \mathrm{a}$ & $29.20 \mathrm{~b}$ & $4.89 \mathrm{~b}$ & $0.37 \mathrm{~b}$ \\
\hline Talc & $79 \mathrm{~b}$ & $1.86 \mathrm{a}$ & $17.53 \mathrm{a}$ & $15.37 \mathrm{a}$ & $1.27 \mathrm{a}$ \\
\hline Limestone & $86 \mathrm{ab}$ & $1.70 \mathrm{a}$ & $19.36 \mathrm{a}$ & $15.21 \mathrm{a}$ & $1.32 \mathrm{a}$ \\
\hline \multicolumn{6}{|c|}{ Cementing material } \\
\hline $\mathrm{Ga}$ & $86 \mathrm{a}$ & $1.53 \mathrm{a}$ & $22.74 \mathrm{a}$ & $10.76 \mathrm{a}$ & $0.90 \mathrm{a}$ \\
\hline PVA & $89 \mathrm{a}$ & $1.67 \mathrm{a}$ & $21.32 \mathrm{a}$ & $12.89 \mathrm{a}$ & $1.07 \mathrm{a}$ \\
\hline $\mathrm{CV}(\%)$ & 15.54 & 34.08 & 11.11 & 36.20 & 31.22 \\
\hline
\end{tabular}

Filling material: Starch = manioc starch; Talc: inert talc; Limestone = dolomitic limestone.

Cementing material: Ga = Gum arabic; PVA = Polyvinyl acetate.

ns - comparison between control and treatments, not significant by the F test at the $5 \%$ level.

** - comparison between control and treatment, significant by the $\mathrm{F}$ test at the $1 \%$ level.

Means followed by the same letter, in the column and within each factor, do not differ among themselves by the Tukey test, at a $5 \%$ probability level. 


\section{Conclusions}

The process of pelletizing the cubiu seeds provides increase of mass and diameter of the propagation unit.

Pelletizing does not affect the germination process, but the physical barrier imposed on the seeds delays germination only in the laboratory.

The pellets made with dolomitic limestone and polyvinyl acetate have the best germination and vigor results.

\section{Acknowledgments}

The authors would like to thank the Improvement of Higher Education Personnel (CAPES) for the scholarship and the National Institute of Amazonian Research (INPA) by the conditions offered that allowed the accomplishment of this study.

\section{References}

ANDRADE JUNIOR, M.C.; ANDRADE, J.S.; COSTA, S.S.; LEITE, E.A.S. Nutrients of cubiu fruits (Solanum sessiliflorum Dunal, Solanaceae) as a function of tissues and ripening stages. Journal of Food and Nutrition Research, Bratislava, v.5, n.9, p.674-683, 2017.

BOMFIM, G.F.A.; VASCONCELOS,E.S.;ANDREAZZA, G.; ACHRE, D.; CAZZO, V.N. Germinação e emergência de plântulas associadas ao tamanho e peletização de sementes de quinoa. Scientia Agraria Paranaensis, Marechal Cândido Rondon, v.15, n.3, p.298-304, 2016.

BRASIL. Ministério da Agricultura, Pecuária e Abastecimento. Regras para análise de sementes. Brasília: Mapa/ACS, 2009. 399 p.

CALDEIRA, C.M.; CARVALHO, M.L.M.; GUIMARÃES, R.M.; COELHO, S.V.B. Qualidade de sementes de tabaco durante o processo de pelotização e armazenamento. Ciência Rural, Santa Maria, v.46, n.2, p.216-220, 2016.

CARVALHO, C.; NOVEMBRE, A.D.L.C. Avaliação da qualidade de sementes de fumo, nuas e revestidas, pelo teste de condutividade elétrica. Revista Brasileira de Sementes, Londrina, v.33, n.1, p.177-185, 2011.

DODE, J.S.; MENEGHELLO, G.E.; MORAES, D.M.; PESKE, S.T. Teste de respiração para avaliar a qualidade fisiológica de sementes de girassol. Revista Brasileira de Sementes, Londrina, v.34, n.4, p.686-691, 2012.
DONADIO, L.C.; ZACCARO, R.P. Valor nutricional de frutas. Jaboticabal: SBF/Coopercitrus, 2012. 248p.

GADOTTI, C.; PUCHALA, B. Revestimento de sementes. Abrates, Londrina, v.20, p.70-71, 2010.

HÖLBIG, L.S.; BAUDET, L.; VILLELA, F.A.; CAVALHEIRO, V. Recobrimento de sementes de cenouras osmocondicionadas. Revista Brasileira de Sementes, Londrina, v.32, n.4, p.22-28, 2010.

LABOURIAU, L.G. A germinação das sementes. Washington: Secretaria Geral da Organização dos Estados Americanos, 1983. 174p.

LOPES, A.C.A.; NASCIMENTO, W.M. Peletização de sementes de hortaliças. Brasília: Embrapa, 2012. 28p.

LOPES, J.C.; PEREIRA, M.D. Germinação de sementes de cubiu em diferentes substratos e temperaturas. Revista Brasileira de Sementes, Londrina, v.27, n.2, p.146-150, 2005.

LUDWIG, M.P.; FILHO, O.A.L.; BAUDET, L.; DUTRA, L.M.C.; AVELAR, S.A.G.; CRIZEL, R.L.; OLIVEIRA, S. De. Eficiência do recobrimento de sementes de soja em equipamento com sistema de aspersão. Ciência Rural, Santa Maria, v.41, n.4, p.557-563, 2011.

MAGUIRE, J.D. Speed of germination-aid in selection and evaluation for seedling emergence and vigor. Crop Science, Madison, v.2, p.176-177, 1962.

MENDONÇA, E.A.F.; CARVALHO, N.M.; RAMOS, N.P. Revestimento de sementes de milho superdoce (sh2). Revista Brasileira de Sementes, Londrina, v.29, n.2, p.68-79, 2007.

NAKAGAWA, J. Testes de vigor baseados no desempenho das plântulas. In: KRZYZANOSKI, F.C.; VIEIRA, R.D.; FRANÇA NETO, J.B. (Ed.). Vigor de sementes: conceitos e testes. Londrina: ABRATES, 1999. p.1-24.

NASCIMENTO, W.N.; SILVA, J.B.C.; SANTOS, P.E.C.; CARMONA, R. Germinação de sementes de cenoura osmoticamente condicionadas e peletizadas com diversos ingredientes. Horticultura Brasileira, Vitoria da Conquista, v.27, n.1, p.12-16, 2009.

PEREIRA, C.E.; OLIVEIRA, J.A.; GUIMARÃES, R.M.; VIEIRA, A.R.; EVANGELISTA, J.R.E.; OLIVEIRA, G.E. Tratamento fungicida e peliculização de sementes de soja submetidas ao armazenamento. Ciência e Agrotecnologia, Lavras, v.35, p.158-164, 2011. 
QUEIROZ, R.L.; ROSA, E.S.M.D.; MARQUES, M.; GOULART, V.A.; MARQUES, G.F. Formação de mudas de alface provenientes de sementes peletizadas com altas diluições. Revista Fitos, Jacarepaguá, v.9, n.3, p.161-252, 2015.

SAMPAIO, T.G.; SAMPAIO, N.V. Recobrimento de sementes de hortaliças. In: NASCIMENTO, W. M. (Ed.). Tecnologia de sementes de hortaliças. Brasília: Embrapa Hortaliças, 2009. p.275-306.

SANTOS, L.D.C.; BENETT, C.G.S.; SILVA, K.S.; SILVA, L.V. Germinação de diferentes tipos de sementes de Brachiaria brizantha cv. BRS PIATÃ. Bioscience Journal, Uberlândia, v.27, n.3, p.420-426, 2011.

SANTOS, S.R.G. Peletização de sementes florestais no Brasil: Uma atualização. Floresta e Ambiente, Seropédica, v.23, n.2, p.286-294, 2016.

SIKHAO, P.; TAYLOR, A.G.; MARINO, E.T.; CATRANIS, C.M.; SIRI, B. Development of seed agglomeration technology using lettuce and tomato as model vegetable crop seeds. Scientia horticulturae, Amsterdam, v.184, p.85-92, 2015.

SILVA FILHO, D. F.; MACHADO, F. M.; NODA, H.; YUYAMA, L. K. O.; AGUIAR, J. P. L.; SOUZA, V. G. Cubiu (Solanum sessiliflorum Dunal): aspectos agronômicos e nutricionais. INPA, Manaus, 2012b. 39p.

SILVA FILHO, D.F.; NODA, H.; MACHADO, F.M. Cultivares de cubiu (Solanum sessiliflorum Dunal) para olericultura sustentável da Amazônia. In: NODA, H.; SOUZA, L. A. G.; SILVA FILHO, D. F. (Ed.). Pesquisas agronômicas para a agricultura sustentável na Amazônia Central. Manaus: WEGA, 2013. p.27-42.
SILVA FILHO, D.F.; SOARES, J.E.C.; VASQUES, M.S.; MARTINS, A.L.U.; NODA, H.; MACHADO, F.M.; NODA, S.N. Potencial das etnovariedades de cubiu (Solanum sessiliflorum Dunal, Solanaceae) da região do alto rio negro, avaliado por análises morfológica e agronômica. In: SOUZA, L.A.G.; CASTELLÓN, E.G. (Ed.). Desvendando as fronteiras do Conhecimento na Região Amazônica do Alto Rio Negro. Manaus: INPA, 2012a, p.147-169.

SILVA, F.A.S.; AZEVEDO, C.A.V. The Assistat software version 7.7 and its use in the analysis of experimental data. African Journal of Agricultural Research, Nairóbi, v.11, n.39, p.3733-3740, 2016.

SILVA, J.B.C.; NAKAGAWA, J. Confecção e avaliação de péletes de sementes de alface. Horticultura Brasileira, Brasília, DF, v.16, n.2, p.151-158, 1998.

SILVA, J.B.C.; NASCIMENTO, W.M. Peletização de sementes de hortaliças. In: NASCIMENTO, W. M. (Ed.). Tecnologia de sementes de hortaliças. Brasília, DF: Embrapa Hortaliças, 2009. p.309-341.

SOUSA, P.G.F.; VIEIRA, H.D.; AMORIM, M.M.; ACHA, A.J. Coating with fungicide and different doses of fertilizer in vinhatico seeds. African Journal of Biotechnology, Nairóbi, v.15, n.38, p.2091-2097, 2016.

TAVARES, L.C.; RUFINO, C.A.; DÖRR, C.S.; BARROS, A.C.S.A.; PESKE, S.T. Performance of lowland rice seeds coated with dolomitic limestone and aluminum silicate. Revista Brasileira de Sementes, Londrina, v.34, n.2, p.202-211, 2012. 